\title{
Distribusi Nrf2 dan Enzim GST pada Sel Granulosa Ovarium Tikus Putih Premenopause setelah Pemberian Serbuk Kunyit
}

\section{Distribution of Nrf2 and GST Enzyme in Premenopausal White Rat Ovarian Granulosa Cells after Administration of Turmeric Powder}

\author{
Teguh Suprihatin ${ }^{1 *}$, Sri Rahayu ${ }^{2}$, Muhaimin Rifa'i ${ }^{2}$, Sri Widyarti ${ }^{2}$ \\ ${ }^{1}$ Program Studi Biologi Fakultas Sains dan Matematika Universitas Diponegoro Semarang \\ ${ }^{2}$ Program Doktor Biologi Fakultas Matematika Ilmu Pengetahuan Alam Universitas Brawijaya Malang \\ *Email: teguhsuprihatin@lecturer.undip.ac.id
}

Diterima 3 Maret 2021 / Disetujui 26 April 2021

\begin{abstract}
ABSTRAK
Kurkumin pada tanaman kunyit dapat mengaktivasi agen transkripsi yaitu Nuclear related factor 2 (Nrf2). Nrf2 berperan dalam transkripsi kelompok enzim detoksifikasi fase II, seperti glutathione S-transferase (GST). Enzim GST dapat berfungsi sebagai antioksidan dengan melindungi sel dari radikal bebas terutama dari kelompok ROS. Penelitian bertujuan mengetahui distribusi Nrf2 dan enzim GST pada sel granulosa ovarium tikus putih premenopause, setelah pemberian serbuk rimpang kunyit. Hewan uji yang digunakan adalah 30 ekor tikus putih betina, strain wistar, usia 12 bulan, dengan bobot 200-250 g. Enam kelompok perlakuan, yaitu $\mathrm{P} 0$; kontrol negatif, diberi akuades $4 \mathrm{ml}, \mathrm{P} 1$; kontrol positif, diberi serbuk kurkumin dosis $6,75 \mathrm{mg} / \mathrm{kg} \mathrm{BB}, \mathrm{P} 2$; diberi serbuk rimpang kunyit dosis $100 \mathrm{mg} / \mathrm{kg} \mathrm{BB}, \mathrm{P} 3$; diberi serbuk rimpang kunyit dosis $200 \mathrm{mg} / \mathrm{kg} \mathrm{BB}, \mathrm{P} 4$; diberi serbuk rimpang kunyit dosis $400 \mathrm{mg} / \mathrm{kg} \mathrm{BB}$, dan P5; diberi serbuk rimpang kunyit dosis $800 \mathrm{mg} / \mathrm{kg} \mathrm{BB}$. Perlakuan per oral setiap hari selama 27 hari. Penelitian menggunakan Rancangan Acak Lengkap, data distribusi Nrf2 dan GST dianalisis menggunakan ANOVA dan dilanjutkan dengan BNJ. Kesimpulan penelitian adalah pemberian serbuk rimpang kunyit dosis $200 \mathrm{mg} / \mathrm{kg} \mathrm{BB}$, merupakan dosis optimal dalam meningkatkan distribusi $N r f 2$ dan enzim GST pada sel granulosa ovarium tikus putih premenopause.
\end{abstract}

Kata kunci: radikal bebas, agen transkripsi, enzim detoksifikasi fase II, kurkumin.

\begin{abstract}
Curcumin in turmeric plants can activate a transcription agent, namely Nuclear related factor 2. Nrf2 plays a role in the transcription of phase II detoxification enzyme groups, such as glutathione S-transferase. GST enzymes can function as antioxidants by protecting cells from free radicals, especially from the ROS. The aim of this study was to see distribution of Nrf2 and GST enzymes in granulosa cells of premenopausal white rats, after presenting turmeric powder. Animals used were 30 female white rats, Wistar strain, 12 months old, weighing 200-250 g. Six treatment groups, namely P0; negative control, given distilled water $4 \mathrm{ml}, \mathrm{P} 1$; positive control, given curcumin powder $6.75 \mathrm{mg} / \mathrm{kg} \mathrm{BW}, \mathrm{P} 2$; given turmeric powder $100 \mathrm{mg} / \mathrm{kg} \mathrm{BW}, \mathrm{P} 3$; given turmeric powder $200 \mathrm{mg} / \mathrm{kg} \mathrm{BW}, \mathrm{P} 4$; given turmeric powder $400 \mathrm{mg} / \mathrm{kg} \mathrm{BW}$, and P5; given turmeric powder $800 \mathrm{mg} / \mathrm{kg} \mathrm{BW}$. Treatment orally every day for 27 days. The study used a completely randomized design, the distribution of Nrf2 and GST data was analyzed using ANOVA and BNJ test. The results showed that administration of turmeric powder at a dose of $200 \mathrm{mg} / \mathrm{kg} \mathrm{BW}$ was the optimal dose to increase the distribution of Nrf2 and GST enzymes in granulosa cells of premenopausal rats.
\end{abstract}

Keywords: free radicals, transcription agents, phase II detoxification enzymes, curcumin. 


\section{PENDAHULUAN}

Kandungan kurkuminoid merupakan dasar penilaian dari kualitas rimpang kunyit, semakin tinggi kandungan kurkuminoid pada rimpang kunyit atau serbuk kunyit maka akan semakin tinggi pula nilai ekonomisnya (Li et al., 2011). Kandungan kurkumin dalam rimpang kunyit bervariasi sesuai dengan jenis kultivar tanaman kunyit, usia panen, ukuran atau jenis rimpang (rimpang induk atau rimpang anakan), dan kondisi tanah (daerah, iklim, musim) (Lokhande et al., 2013). Kandungan kurkumin pada rimpang kunyit (Curcuma longa) adalah 3-8 \%, paling tinggi dibandingkan dengan rimpang kunyit putih (Curcuma zedoaria) 0,1\%, dan rimpang temu lawak (Curcuma xanthorrhiza) $1,2 \%$ (Chattopadhyay et al., 2004).

Kurkumin merupakan suatu senyawa elektrofilik yang dapat mengaktivasi signaling pathway dari Nrf2 (Nuclear related factor 2). Nrf2 mempunyai peran penting dalam aktivasi enzim-enzim antioksidan (Sikora et al., 2010). Penelitian Kitani et al., (2007) pada Mus musculus usia 13 bulan yang diberi pakan dengan suplementasi kurkumin 0,2 \% menunjukkan dapat meningkatkan lama hidup (lifespan) rata-rata $11,7 \%$. Hal ini diduga karena kurkumin dapat mengaktivasi signaling pathway dari Nrf2, yang kemudian akan meningkatkan regulasi enzim-enzim antioksidan yang bertugas melindungi sel dari radikal bebas (Toden and Goel., 2017).

Penelitian Zhuang et al., (2013) menunjukkan bahwa kurkumin dapat mengaktivasi Nrf2 pada sitoplasma sel melalui penghambatan ikatan antara $N r f 2$ dengan protein Keapl. Apabila ikatan antara $N r f 2$ dengan Keapl terhambat atau terlepas, maka selanjutnya $N r f 2$ akan dapat masuk ke dalam nukleus dan akan mempengaruhi proses transkripsi enzim-enzim antioksidatif dari kelompok enzim detosifikasi fase II (phase II detoxification enzymes) seperti glutathione S-transferase (GST), NAD $(P) H \quad$ quinone oxireductase 1 (NQO1) dan glutamylcystein synthetase (GCS) (Zhang, 2006). Enzim-enzim anti oksidatif ini selanjutnya akan melindungi sel dari radikal bebas terutama dari kelompok $R O S$ (Reyes et al., 2013).

Penelitian ini berusaha mengkaji tentang potensi senyawa kurkumin pada serbuk rimpang kunyit dalam mengaktivasi $\mathrm{Nrf} 2$ dan memicu transkripsi enzim detoksifikasi fase 2 yaitu enzim GST, pada sel granulosa ovarium tikus putih kondisi premenopause.

\section{METODE PENELITIAN}

\section{Rancangan Penelitian dan Analisis Data}

Penelitian ini merupakan penelitian eksperimental laboratorik, dengan menggunakan Rancangan Acak Lengkap (RAL) yang terdiri-dari 6 kelompok perlakuan. Pada setiap kelompok perlakuan, dilakukan ulangan sebanyak 5 kali. Kelompok perlakuan tersebut adalah berturut-turut sebagai berikut, P0 : kelompok kontrol negatif tanpa pemberian serbuk rimpang kunyit (hanya diberi pakan standar dan akuades), P1 : kelompok kontrol positif dengan pemberian serbuk kurkumin dosis $6,75 \mathrm{mg} / \mathrm{kg}$ BB, P2 : kelompok perlakuan dengan pemberian serbuk rimpang kunyit dosis $100 \mathrm{mg} / \mathrm{kg}$ BB, P3 : kelompok perlakuan dengan pemberian serbuk rimpang kunyit dosis $200 \mathrm{mg} / \mathrm{kg}$ $\mathrm{BB}, \mathrm{P} 4$ : kelompok perlakuan dengan pemberian serbuk rimpang kunyit dosis $400 \mathrm{mg} / \mathrm{kg} \mathrm{BB}, \mathrm{P} 5$ : kelompok perlakuan dengan pemberian serbuk rimpang kunyit dosis $800 \mathrm{mg} / \mathrm{kg} \mathrm{BB}$.

\section{Hewan Uji}

Hewan uji adalah tikus putih betina (Rattus norvegicus) strain Wistar, yang sudah berusia 12 bulan dan diperkirakan sudah memasuki usia premenopause, bobot tikus antara 200-250 g, sebanyak 30 ekor. Perlakuan serbuk kurkumin dan serbuk rimpang kunyit diberikan setiap hari per oral selama 27 hari.

\section{Serbuk Kurkumin dan Serbuk Rimpang Kunyit}

Serbuk kurkumin yang digunakan pada penelitian ini merupakan produk dari perusahaaan Sigma-Aldrich dengan nomor seri katalog C1386-5G. Serbuk kurkumin yang digunakan 
mempunyai kemurnian sekitar $85 \%$, seperti yang tertera pada keterangan label produk. Serbuk kurkumin dalam bentuk kristal yang merupakan ekstrak dari tanaman kunyit (Curcuma longa).

Serbuk Rimpang kunyit diperoleh dari Laboratorium Balai Penelitian Tanaman Rempah dan Obat (Balittro), Bogor. Rimpang kunyit dipanen dari tanaman kunyit (Curcuma longa) yang telah berusia lebih dari 8 bulan, dipilih rimpang utama dengan panjang sekitar 5-7 cm dan diameter 1-1,5 cm. Rimpang kunyit dibersihkan dengan dicuci menggunakan air sampai bersih kemudian diiris tipis dan dikering-anginkan sampai kering. Pengeringan dilakukan selama kurang lebih 2 minggu sampai kandungan air hanya tinggal sekitar $10 \%$. Irisan tipis rimpang kunyit yang sudah kering kemudian diblender sampai terbentuk serbuk rimpang kunyit (turmeric). Selanjutnya dilakukan pengayakan pada serbuk rimpang kunyit dengan menggunakan ayakan yang berukuran 200 mesh.

\section{Preparasi Histologi dan Pewarnaan Imunohistokimia}

Hari ke-28 penelitian diakhiri, hewan coba kemudian didislokasi leher dan dilanjutkan dengan pembedahan untuk isolasi organ ovarium. Preparasi histologis ovarium menggunakan metode parafin dan dilanjutkan dengan pewarnaan imunohistokimia. Slide preparat hasil pewarnaan imunohistokimia kemudian diamati dibawah mikroskop untuk menghitung distribusi $N r f 2$ dan Enzim GST. Pembuatan preparat histologis organ ovarium pada penelitian ini menggunakan metode parafin dengan pewarnaan berdasarkan prosedur Suntoro (1983).

Pewarnaan imunohistokimia menggunakan prosedur dari Boenisch (2001). Antibodi primer yang digunakan adalah produk dari Abcam, yaitu mouse monoclonal anti-Nrf2 antibody dengan nomor seri katalog ab62352 untuk mengetahui distribusi Nrf2, dan antibodi primer mouse monoclonal anti-GST antibody dengan nomor katalog ab170323 untuk mengetahui distribusi enzim GST.

\section{Analisis Data}

Data distribusi $N r f 2$ dan enzim GST yang diperoleh dari hasil pengamatan preparat, dianalisis menggunakan ANOVA dan dilanjutkan dengan analisis BNJ, masing-masing pada taraf kepercayaan 95\%. Semua data hasil penelitian diolah menggunakan software komputer program SPSS for Windows versi 22.

\section{HASIL DAN PEMBAHASAN}

Hasil pembuatan preparat menggunakan metode parafin dan dilanjutkan dengan pewarnaan imunohistokimia (IHK), pada sel granulosa ovarium tikus putih premenopause setelah pemberian serbuk rimpang kunyit tampak pada Gambar 1 dan 2. Preparat ini digunakan untuk menghitung distribusi Nrf2 dan enzim GST pada sel granulosa ovarium tikus putih premenopause setelah pemberian serbuk rimpang kunyit. Penghitungan distribusi Nrf2 dan enzim GST pada preparat dilakukan dibawah mikroskop. Hasil ANOVA dan analisis BNJ data distribusi Nrf2 dan enzim GST pada sel granulosa ovarium tikus putih premenopause setelah pemberian serbuk rimpang kunyit ditampilkan pada Tabel 1.

Hasil ANOVA dan analisis BNJ data distribusi $N r f 2$ pada sel granulosa ovarium tikus putih premenopause setelah perlakuan serbuk rimpang kunyit, menunjukkan adanya perbedaan secara signifikan antara kelompok perlakuan serbuk kurkumin dengan kelompok kontrol negatif (akuades), sedangkan kelompok perlakuan serbuk rimpang kunyit berbeda tidak signifikan dengan kelompok kontrol negatif (akuades), tetapi kecenderungannya menunjukkan peningkatan distribusi $N r f 2$ seiring dengan peningkatan dosis serbuk kunyit yang diberikan.

Hasil ANOVA dan analisis BNJ data distribusi enzim GST pada sel granulosa ovarium tikus putih premenopause setelah perlakuan serbuk rimpang kunyit, menunjukkan bahwa kelompok perlakuan serbuk kurkumin dan kelompok perlakuan serbuk rimpang kunyit dosis 200, 400, dan $800 \mathrm{mg} / \mathrm{kg} \mathrm{BB}$, berbeda secara signifikan dibandingkan dengan kelompok perlakuan kontrol negatif yang hanya diberi perlakuan akuades. 
Tabel 1. Rerata distribusi Nrf2 dan Enzim GST pada sel granulosa ovarium tikus putih premenopouse setelah pemberian serbuk kunyit (\%)

\begin{tabular}{|c|c|c|c|c|c|c|}
\hline \multirow[t]{2}{*}{ Parameter } & \multirow{2}{*}{$\begin{array}{l}\text { Akuades } \\
\pm \text { SD }\end{array}$} & Kurkumin & \multirow{2}{*}{$\begin{array}{l}\text { Dosis } \\
\mathrm{mg} / \mathrm{kg} \\
\pm \mathrm{SD}\end{array}$} & \multirow{2}{*}{$\begin{array}{l}\text { Dosis } \\
\mathrm{mg} / \mathrm{kg} \\
\pm \mathrm{SD}\end{array}$} & \multirow{2}{*}{$\begin{array}{l}\text { Dosis } \\
\mathrm{mg} / \mathrm{kg} \\
\pm \mathrm{SD}\end{array}$} & \multirow{2}{*}{$\begin{array}{ll}\text { Dosis } & 800 \\
\mathrm{mg} / \mathrm{kg} & \text { BB } \\
\pm \mathrm{SD} & \end{array}$} \\
\hline & & $\begin{array}{lr}\text { dosis } & 6,75 \\
\mathrm{mg} / \mathrm{kg} & \mathrm{BB} \\
\pm \mathrm{SD} & \\
\end{array}$ & & & & \\
\hline Nrf2 & $26,22^{a} \pm 2,37$ & $34,55^{\mathrm{b}} \pm 2,19$ & $26,89^{\mathrm{ab}} \pm 0,92$ & $26,94^{\mathrm{ab}} \pm 2,55$ & $29,27^{\mathrm{ab}} \pm 4,97$ & $31,55^{\mathrm{ab}} \pm 2,86$ \\
\hline Enzim $G S T$ & $47,05^{a} \pm 3,42$ & $72,94^{b} \pm 2,86$ & $61,16^{\mathrm{ab}} \pm 4,85$ & $69,89^{b} \pm 7,16$ & $69,16^{\mathrm{b}} \pm 9,11$ & $69,83^{\mathrm{b}} \pm 8,66$ \\
\hline
\end{tabular}

Keterangan : angka-angka dengan superskrip huruf yang berbeda pada lajur yang sama menunjukkan berbeda nyata $(\alpha<0,05)$.

Kurkumin terbukti dapat meningkatkan distribusi $N r f 2$ pada sel granulosa ovarium tikus putih premenopause, selanjutnya peningkatan $N r f 2$ akan berimbas pada peningkatan distribusi enzim GST. Hal ini terbukti dengan hasil penelitian yang menunjukkan adanya peningkatan distribusi GST secara signifikan setelah perlakuan serbuk rimpang kunyit dosis 200, 400, dan $800 \mathrm{mg} / \mathrm{kg} \mathrm{BB}$, dengan peningkatan distribusi GST tertinggi pada perlakuan serbuk rimpang kunyit dosis $200 \mathrm{mg} / \mathrm{kg}$ BB, yaitu sebesar 48,54\% dibandingkan dengan kontrol negatif.

Kelompok hewan coba yang diberi perlakuan serbuk kurkumin (kontrol positif) dan kelompok hewan coba yang diberi perlakuan serbuk rimpang kunyit dosis 200, 400, dan 800 $\mathrm{mg} / \mathrm{kg} \mathrm{BB}$, menunjukkan peningkatan distribusi enzim GST (Glutathione S-Tranferase) secara signifikan dibandingkan dengan kelompok kontrol negatif (akuades). Peningkatan distribusi Enzim GST setelah perlakuan serbuk kurkumin dan serbuk rimpang kunyit diduga karena adanya kandungan kurkumin yang merupakan senyawa elektrofilik yang dapat berfungsi sebagai faktor transkripsi dengan mengaktivasi signaling pathway dari $\mathrm{Nrf2}$ di dalam sitoplasma sel dengan cara menghambat ikatan antara Nrf2 dengan protein Keapl (Reyes et al., 2013).

Tahapan premenopause pada individu betina, secara umum ditandai dengan menurunnya kadar hormon progesteron, hormon estrogen, dan siklus reproduksi yang tidak teratur (Doshi and Agarwal, 2014). Premenopause juga dapat ditandai dengan penurunan jumlah dan kualitas folikel pada ovarium (Li et al., 2012). Penyebab utama penurunan jumlah dan kualitas folikel pada ovarium, diduga karena adanya peningkatan kadar radikal bebas, yang terutama berasal dari kelompok ROS (Radical Oxygen Species) (Tatone and Amicarelli, 2013). Radikal bebas dari kelompok ROS, meliputi radikal superoksida anion, radikal hidroksil, dan hidrogen peroksida (Halliwell and Gutteridge, 2015).

ROS merupakan produk metabolisme aerobik normal, dalam membran mitokondria selama proses fosforilasi oksidatif dan produksi energi. Carbonil Reactive Spesies (CRS) juga merupakan kelompok radikal bebas yang berasal dari metabolisme endogen sel yaitu proses glikolisis (Kunwar and Priyadarsini, 2011). Peningkatan produksi radikal bebas karena kebocoran elektron intra-mitokondria diduga erat hubungannya dengan faktor pertambahan usia dan aging (Agarwal et al., 2012).

Produksi radikal bebas yang melebihi kemampuan fungsi antioksidan endogen, akan mengakibatkan terjadinya gangguan pada metabolisme sel, kerusakan sel, dan dapat berujung pada terjadinya kematian sel (Bruns et al., 2015). Ketidak-seimbangan antara produksi radikal bebas dan antioksidan, akan menyebabkan gangguan kinerja seluler dan energi yang dilepaskan dari mitokondria, yang akhirnya akan mengarah pada kerusakan dan kematian sel (Subrat et al., 2013).

Pemberian serbuk rimpang kunyit dapat meningkatkan jumlah folikel pada ovarium tikus putih premenopause (Suprihatin et al., 2020), karena kemampuan senyawa kurkumin yang terdapat pada serbuk rimpang kunyit dapat 
berfungsi sebagai antioksidan dan bersifat sitoprotektif. Serbuk rimpang kunyit pada penelitian ini terbukti dapat meningkatkan distribusi Nrf2 dan enzim GST. Peningkatan distribusi Nrf2 dan enzim GST ini disebabkan oleh adanya kandungan senyawa kurkumin pada serbuk rimpang kunyit yang diberikan (Itoh et al., 1999).

Peningkatan distribusi $N r f 2$, akibat adanya senyawa kurkumin yang terkandung dalam serbuk rimpang kunyit akan menghalangi ikatan antara Nrf2 dengan Keapl (Meizarini et al., 2018). Apabila ikatannya tidak terbentuk atau terlepas, maka $N r f 2$ menjadi aktif dan akan masuk ke dalam nukleus. Nrf2 di dalam nukleus akan berikatan dengan sMaf (small Maf) dan mengaktivasi ARE (Antioxidant Response Element) (Paladino et al., 2018) untuk mentranskripsi gen-gen pembentuk enzim sitoprotektif seperti enzim GST
(Gluthatione $S$ Transferase), yang merupakan enzim penting dalam perlindungan sel dari kerusakan yang disebabkan radikal bebas (Suzuki and Yamamoto., 2015).

Kerja enzim GST adalah menghambat $P 21$ sebagai inhibitor siklus sel. $P 21$ yang tidak aktif, akan memicu siklus sel untuk dapat kembali berjalan karena $E 2 F$ sebagai faktor transkripsi untuk Cyclin E menjadi aktif kembali. Cyclin $E$ diperlukan oleh sel untuk masuk ke fase $\mathrm{S}$ (Homma et al., 2009). Peningkatan fase S dapat diartikan terjadi peningkatan proliferasi sel granulosa ovarium. Kecenderungan peningkatan proliferasi sel berdasarkan penelitian Velasquez et al., (2014), yang menyatakan bahwa pemberian $0,5 \mu \mathrm{M}$ kurkumin pada stem sel olfaktori dapat menstimulasi terjadinya proliferasi sel.
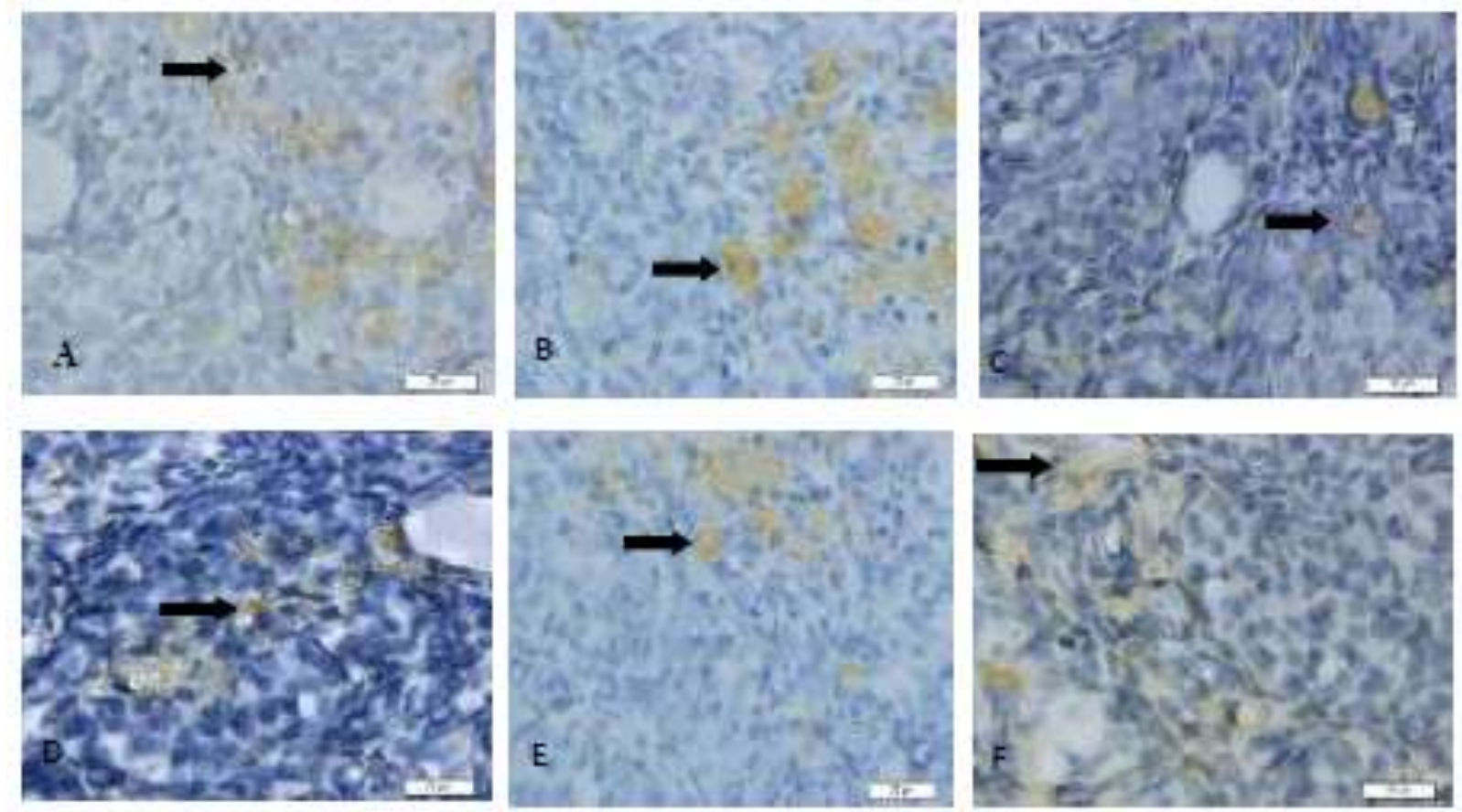

Gambar 1 : Distribusi Nrf2 pada sel granulosa ovarium tikus putih premenopause dengan metode IHK setelah perlakuan. Sel granulosa berwarna coklat yang ditunjukkan dengan tanda panah warna hitam menunjukkan positif Nrf2. A. kontrol negatif (akuades), B. kontrol positif (serbuk kurkumin), C. serbuk rimpang kunyit dosis $100 \mathrm{mg} / \mathrm{kg} \mathrm{BB}$, D. dosis $200 \mathrm{mg} / \mathrm{kg} \mathrm{BB}$, E. dosis $400 \mathrm{mg} / \mathrm{kg} \mathrm{BB}, \mathrm{F}$. dosis $800 \mathrm{mg} / \mathrm{kg}$ BB. Perbesaran 1000x menggunakan mikroskop bright field merk Olympus seri BX53. 

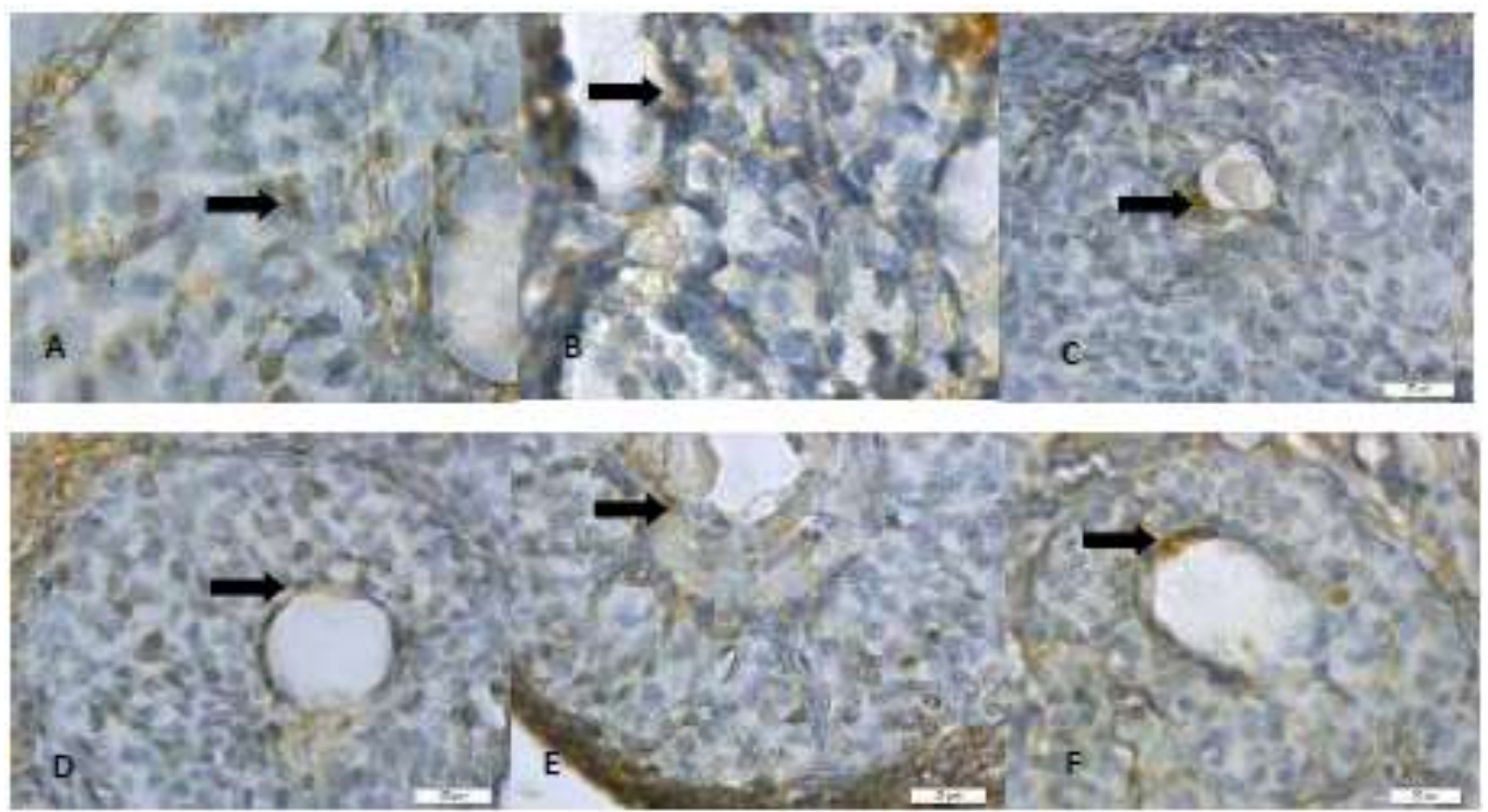

Gambar 2 : Distribusi enzim GST pada sel granulosa ovarium tikus putih premenopause dengan metode IHK setelah perlakuan Sel granulosa berwarna coklat yang ditunjukkan dengan tanda panah warna hitam menunjukkan positif enzim GST. A. kontrol negatif (akuades), B. kontrol positif (serbuk kurkumin), C. serbuk rimpang kunyit dosis $100 \mathrm{mg} / \mathrm{kg} \mathrm{BB}$, D. dosis $200 \mathrm{mg} / \mathrm{kg} \mathrm{BB}, \mathrm{E}$. dosis $400 \mathrm{mg} / \mathrm{kg} \mathrm{BB}, \mathrm{F}$. dosis $800 \mathrm{mg} / \mathrm{kg}$ BB. Perbesaran 1000x menggunakan mikroskop bright field merk Olympus seri BX53.

\section{KESIMPULAN}

Pemberian serbuk rimpang kunyit dosis $200 \mathrm{mg} / \mathrm{kg}$ BB merupakan dosis optimal dalam meningkatkan distribusi Nrf2 dan enzim GST pada sel granulosa ovarium tikus putih premenopause.

\section{UCAPAN TERIMA KASIH}

Artikel merupakan bagian dari disertasi penulis pertama. Studi program doktor telah dibiayai oleh beasiswa BPPDN, Direktorat Jenderal, Kementerian Riset, Teknologi dan Pendidikan Tinggi, Republik Indonesia.

\section{DAFTAR PUSTAKA}

Agarwal, A., A. Aponte-Mellado, B.J. Premkumar, A. Shaman, S. Gupta. 2012. The effects of oxidative stress on female reproduction: a review. Reproductive Biology and Endocrinology. 10:1-49.
Boenisch, T. 2001. Immunohistochemical Handbook; Antibodies. 3rd edition. DAKO Corporation. California.

Bruns, D.R., J.C. Drake, L.M. Biela. 2015. Nrf2 signaling and the slowed aging phenotype: evidence from long-lived models. Oxidative Medicine and Cellular Longevity. 16(5)1-15.

Chattopadhyay, I., K. Biswas, U. Bandyopadhyay, R. K. Banerjee. 2004. Turmeric and curcumin: Biological actions and medicinal applications. Current Science. 87:44-50.

Doshi, S.B., A. Agarwal. 2014. The role of oxidative stress in menopause. Journal of Mid-life Health. 4(3):140-147.

Halliwell, B., J. M. C. Gutteridge. 2015. Free Radical in Biology Medicine $5^{\text {th }}$ Edition (preview). Oxford University Press. Oxford. United Kingdom. 
Homma, S., Y. Ishii, Y. Morishima, T. Yamadori, Y. Matsuno. 2009. Nrf2 Enhances cell proliferation and resistance to anticancer drugs in human lung cancer. Clinical Cancer Research.15(10):3423-3434.

Itoh, K., N. Wakabayashi, Y. Katoh, T. Ishii, K. Igarashi, J.D. Engel, M. Yamamoto. 1999. Keapl represses nuclear activation of antioxidant responsive elements by $\mathrm{Nrf} 2$ through binding to the amino-terminal Neh2 domain. Genes and Development. 13:76-86.

Kitani, K., T. Osawa, T. Yokozawa. 2007. The effects of tetrahydrocurcumin and green tea polyphenol on the survival of male C57BL/6 mice. Biogerontology. 8:567-573.

Kunwar, A., K.I. Priyadarsini. 2011. Free radicals, oxidative stress and importance of antioxidants in human health. Journal of Medical and Allied Sciences, 1(2):53-60.

Li, S., W. Yuan, G. Deng, P. Wang, P. Yang, B.B. Aggarwal, 2011, Chemical composition and product quality control of turmeric (Curcuma longa L.), Pharmaceuti. Crops, 2:28-54

Li, Q., X.D. Geng, W. Zheng, J. Tang, B. Xu, Q.H. Shi. 2012. Current understanding of ovarian aging. Scie. Chi. 55 (8):659-669.

Lokhande, S.M., R.V. Kale, A.K. Sahoo, R.C. Ranveer. 2013. Effect of curing and drying methods on recovery, curcumin and essential oil content of different cultivars of turmeric (Curcuma longa L.). International Food Research Journal. 20(2):745-749.

Meizarini, A., Siswandono, W. Riawan, R.P. Rahayu. 2018. In Silico and In Vivo anti-inflamatory studies of curcuminoids, turmeric extract with zinc oxide, and eugenol. Tropical Journal of Pharmaceutical Research. 17(2):269-275.

Paladino, S. A. Conte, R. Caggiano, G.M. Pierantoni, R. Faraonio. 2018. Nrf2 pathway in age-related neurological disorder: insights into microRNAs. Cellular Physiology and Biochemistry.47:1951-1976.

Reyes, S.G., S.G. Beltrán., O.N. Campos, J.P. Chaverri. 2013. Curcumin Pretreatment Induces Nrf2 and an Antioxidant Response and Prevents Hemin-Induced Toxicity in Primary Cultures of Cerebellar Granule Neurons of Rats. Hindawi Publishing Corporation Oxidative Medicine and Cellular Longevity.http://dx.doi.org/10.1155/2013/801 418.

Sikora, E., G. Scapagnini, M. Barbagallo. 2010 Curcumin, inflammation, ageing and age-related diseases. Immunity Ageing. 7:1-4.

Subrat, P., S.A. Santa, J. Vandana. 2013. The Concepts and Consequences of Early Ovarian Ageing: A Caveat to Women's Health. Journal of Reproduction and Infertility. 14(1):3-7.

Suntoro, H. 1983. Metode Pewarnaan (Histologi dan Histokimia). Penerbit Bharata Karya Aksara. Jakarta.

Suprihatin, T., S. Widyarti, M. Rifa'i, S. Rahayu. 2020. Pengaruh Pemberian Serbuk Rimpang Kunyit (Curcuma longa L.) terhadap Jumlah Folikel Ovarium Tikus Putih (Rattus norvegicus) Premenopause. Buletin Anatomi dan Fisiologi. 5(2):45-52. https://doi.org/10.14710/baf.5.2.2020.\%25p

Suzuki, T., M. Yamamoto. 2015. Molecular basis of the Keap1-Nrf2 system. Free Radical Biology and Medicine. 88(part B):93-100.

Tatone, C., F. Amicarelli. 2012. The aging ovary-the poor granulosa cell. Fertility and Sterility. 99(1):12-17.

Toden, S \& A. Goel. 2017. The holy grail of curcumin and its efficacy in various diseases: is bioavailability truly a big concern?. Journal of Restorative Medicine. 6:27-36.

Velasquez J.T., M.E. Watts, M. Todorovic, L. Nazareth. 2014. Low-dose curcumin stimulates proliferation, migration and phagocytic activity of olfactory ensheathing cells. Plos One 9(10):1-17.

Zhang, D.D. 2006. Mechanistic studies of the nrf2-keapl signaling pathway. Drug Metabolism Reviews. 38(4):769-789.

Zhuang, C., Z. Wu, C. Xing, Z. Miao. 2017. Small molecules inhibiting Keap1-Nrf2 protein-protein interactions: a novel approach 
Distribusi Nrf2 dan Enzim GST pada Sel Granulosa Ovarium Tikus Putih Premenopause setelah Pemberian Serbuk Kunyit

to activate $\mathrm{Nfr} 2$ function. Medicinal

Chemistry Communication. 8:286-294. 